\title{
THE METHODOLOGY FORMING OF ECOLOGICAL COMPETENCY OF FUTURE TEACHERS OF NATURAL SCIENCES DURING VOCATIONAL TRAINING
}

\author{
Inna Siaska \\ PhD, Associate Professor, Rivne State University of Humanities, Ukraine \\ e-mail: syaskainna@gmail.com,orcid.org/0000-0002-6096-1335
}

\section{Summary}

The aim of this paper is to substantiate the effective combination of methodological approaches in the organization of the educational process of professional training of future teachers of natural sciences in the context of the formation of their ecological competency. It is proved that the combination of several methodological approaches (competence, system, personality-oriented, activity, technological, contextual, reflective and coevolutionary-noosphere) on the principle of synergetic interaction will ensure the effectiveness of their combined pedagogical influence in training and is a methodological basis for determining the content, forms, tools and technologies forming of ecological competency of future teachers. It is established that the main role among the mentioned methodological approaches to the organization of the educational process of professional training of future teachers of natural sciences is given to the competence approach. The introduction of a competency-based approach to the practice of higher pedagogical education makes it possible to achieve a number of educational goals. Methodological bases (ontological, epistemological, axiological, praxeological), as well as general and partial pedagogical regularities of competence-oriented education in the process of professional training are determined. They are ensure the effectiveness of the formation of ecological competency of future teachers of natural sciences.

Keywords: methodological approach, pedagogical regularities, methodological bases, students, institution of higher pedagogical education.

\section{DOI: https://doi.org/10.23856/3828}

\section{Introduction}

The focus of pedagogical science was on the issues of education, development, upbringing and socialization of the younger generation with socially demanded qualities, able to realize its full potential in a rapidly changing information society. Therefore, high-quality training of future teachers must meet the social order, and the formation of their professional competency becomes an important area of scientific and pedagogical research. Thus, we can say that the ultimate goal of higher pedagogical education is teacher training, the specificity of which is the need to train a specialist with a wide range of personal competencies, ie one with a number of professional general and professional competencys and relevant experience. The importance of teacher training as a highly qualified, mobile teacher in the context of lifelong learning is emphasized in the European Commission`s Common European Principles for Teachers' Competences and Qualifications program (Common Europe, 2004). It states that the teaching profession has key priorities in shaping the worldview of future generations, preparing students for personal realization as active, responsible and successful citizens. Here is a list of key competencies that a modern teacher should have: to show the ability to work with other people; be able to work with different types of knowledge, technology and information; to work with society and in society. 
The report of the European Commission on the content of the program "Education and Practice 2010" to the general professional competencys of the modern teacher includes the following: the ability to learn independently; ability to analyze their work; ability to conduct research work that is part of professional development; acquisition of a culture of lifelong learning; ability to critically evaluate their professional activity; ability to work in a team (Education and Training 2010 Program, 2008). Thus, a socially in-demand teacher must possess not only professional knowledge and skills, but also certain personal qualities based on a system of values, the ability to reflect, the desire for career growth.

Therefore, the success of the introduction of competence-oriented education as a core procedural concept of professional training of future teachers, in our opinion, will be achieved only if an effective combination of methodological approaches in the educational process based on the principle of logical complementarity, which was the purpose of our study. In accordance with the purpose, the following research tasks were set: to substantiate the methodological approaches to the organization of the educational process of professional training of future teachers; to determine the methodological bases and pedagogical regularities of the implementation of competence-oriented education in the process of professional training, to which the effectiveness of the formation of ecological competency of future teachers of natural sciences is subordinated and ensured.

\section{Methodological approaches in professional training of future teachers}

According to the views of I. V. Blauberg, E. G. Yudin, the methodological approach in pedagogy should be understood as "the principled methodological orientation of research, the point of view from which the object of study is considered (the method of determining the object)" (Blauberg, Yudin, 1973: 74). A similar interpretation is expressed by L. M. Rybalko, who interprets the methodological approach "... as a form of cognitive and practical activity, a set of starting points that determine the research strategy from the appropriate point of view, the basic value orientation" (Rybalko, 2014: 65). Thus, based on the generalization of these definitions, we can conclude that methodological approaches allow to build a strategy of pedagogical activities in order to achieve specific educational goals based on the basic principles, provisions or general pedagogical regularities.

Since educational systems, including pedagogical processes, are dynamic open systems, they are characterized by the ability to self-organize their components through the formation of nonlinear connections between them, which corresponds to the principle of synergy. The latter reflects the theory of self-development of open systems, according to which, according to S.U. Goncharenko, education is transformed from a way of teaching a person into a means of forming an adequate creative personality for this society, which has the synergy for further growth and self-improvement (Goncharenko, 2008: 76). The application of synergetic ideas in pedagogy was investigated by V. G. Kremen, who noted in this regard: "As for pedagogy, the principle of openness is a necessary condition for the pedagogical process, which is self-organizing, when the existing methodologies do not reject, but complement each other. This makes it possible to organically use a variety of pedagogical approaches, methods and technologies..." (Kremen, 2013: 7).

Thus, it is legitimate to conclude that a synergistic combination of methodological approaches will ensure the effectiveness of their combined pedagogical impact in the process of training future teachers of natural sciences. An additional argument is the fact that in the content of professional training of future teachers of biology, physics, chemistry, adaptive to the ideas of synergetics is assumed provides interdisciplinary synthesis of natural sciences in 
order to form a holistic scientific and natural picture of the world. In the context of formation of ecological competence of future teachers an important role in this process is played by mutual strengthening of natural-scientific and social-humanitarian training on the synergetic principle of joint action, which allows future specialists to understand social, economic, political origins of ecological problems, finding effective mechanisms to overcome them and to avoidance in the prognostic perspective.

Therefore, the professional training of future subject teachers in the context of the formation of their ecological competency is considered from the standpoint of competency approach in synergetic combination with systemic, personality-oriented, activity, technological, contextual, reflective and coevolutionary-noosphere methodological approaches.

According to scientists, the systems approach is one of the main methodological approaches in pedagogy. The Ukrainian pedagogical dictionary states that the systematic approach is aimed at revealing the integrity of pedagogical objects, identifying various types of connections and bringing them into a single theoretical picture (Goncharenko, 1997: 305).

System approach, according to A. V. Fokshek, allows "to consider the pedagogical process in terms of its structure, content, functions, set of methods, system connections, the ability to transform the pedagogical skills of the teacher in practice" (Fokshek, 2011: 216). From this we can conclude that the pedagogical process of professional training of future teachers of natural sciences has systemic properties (such as integrity, hierarchical structure, multiplicity of connections) that allow to direct it to achieve a certain educational result - the acquisition of professional competencys, including ecological. The system approach creates methodological bases for constructing a conceptual model of formation of ecological competency of the future teacher in the process of professional training taking into account complex interactions and connections between structural and functional elements of the model, conditions and mechanisms of their functioning. At the same time, we consider the system approach as a methodological substantiation of means and methods of cumulative pedagogical influence on the individual in order to develop certain set qualities: interests, needs, attitudes, motives, values, responsibilities that underlie the genesis of ecological competence of the future specialist.

No less important role in this process is given to the personality-oriented approach, which in pedagogy developed on the priority of the idea of subjectivity in the educational process. In particular, O. M. Piekhota notes that personality-oriented education presupposes “.... cooperation, self-development of the subjects of the educational process, identification of their personal functions" (Piekhota et al., 2001: 31).

Thus, the subject-subject interaction of the participants of the educational process, as the main condition for the implementation of personality-oriented approach, is the necessary basis for the development of intellectual and moral and ethical potential of the individual and his civic responsibility. Based on the psychological mechanisms of formation of consciousness and self-awareness, this approach allows to develop the spiritual sphere of the individual, his system of values and worldviews, which serve as a a necessary, motivating factor of competent professional activity in the future.

At the same time, the implementation of a personality-oriented approach in the training of future teachers in the context of forming a system of competencies creates conditions for interaction between all participants in the educational process on the principles of cooperation, incentives to develop an active position in educational activities and rests on the acquired subjective experience of the higher education applicant, his motivation and ability to self-reflection and self-development. A detailed interpretation of the personality-oriented approach is given in the work of G. K. Selevko, which emphasizes the importance of this approach in creating a 
favorable environment for personal growth of participants in the educational process, and on the other hand is seen as "...a methodological orientation in teaching, which allows through reliance on a system of interrelated concepts, ideas and methods of action to provide and to support the processes of self-knowledge, self-construction and self-realization of the individual, the development of his unique individuality" (Selevko, 2006: 138). Thus, there are grounds for concluding the importance of this approach in the development of personal qualities of students as a basis for the formation of their competency, in particular, ecological.

In turn, the achievement of the goal of the educational process - the acquisition of a number of general and special competencys - is carried out through activities that are adequate to the practical application of knowledge, skills and abilities acquired in the learning process. According to I. V. Burhun, one of the internal factors that determine the introduction of the competency approach is the reorientation of the knowledge paradigm of education to the model of the activity approach (Burhun, 2010).

From the analysis of scientific and pedagogical works we can conclude that the activity approach actualizes the purposeful activity of the person caused by its interests, needs and motives focused on statement and the decision of problems in a certain sphere of activity. From the standpoint of psychology, the effectiveness of education is manifested in the activities of its subject.

In turn, educational activity is characterized by the fact that it is aimed at learning about the object, rather than its transformation by the subjects of activity. In this context, I. D. Bekh notes that the activity approach appeals to the formation of knowledge as beliefs, to the formation of a scientific worldview. To this end, fragments of practice are involved as a testing ground for the application of acquired scientific knowledge (Bekh, 1998: 4). Then really practice serves as a criterion of truth of cognitive results and confirmation of expediency of their application in purposeful professional activity and serves as an indicator of formation of competency of the future specialist. This interpretation confirms the relevance of the activity approach in environmental education of future teachers of natural sciences, because, in our opinion, it is environmental beliefs implemented in practice are the core basis for the formation of their ecological competency and implemented in ecological training of pupils.

The implementation of the activity approach in the professional training of future teachers is closely related to the use of modern pedagogical technologies, so the application of the technological approach in the organization of the educational process of teacher training is relevant and justified.

The expediency of the use, content and functions of modern pedagogical technologies in the educational process of higher education institutions at different times were substantiated in the works of domestic and foreign scientists. From the analysis of these scientific sources we can conclude that pedagogical technologies are considered from two positions:

- as a procedural component of the educational process in an educational institution, which operates with certain educational goals and objectives,

- as a general didactic unit, which is identified with the pedagogical system, as it algorithmically reflects the activities of the holistic educational process.

In particular, according to a study by V. P. Bespalko, pedagogical technology was originally interpreted as training that requires the use of technical means. Over time, there has been an in-depth understanding of the significance of this phenomenon, so the author considers it as the embodiment in practice of a pre-designed educational process, ie pedagogical technology is a project of a particular pedagogical system implemented in practice (Bespalko, 1989: 5-6).

In turn, G. K. Selevko interprets pedagogical technology as a concept with a fairly wide functional load: on the one hand as a means and method of achieving certain educational goals, 
and on the other - as a scientifically based pedagogical system that ensures the functioning of all components of the pedagogical process and leads to predictable results (Selevko, 2006: 35-37).

In the context of substantiation of synergetic combination of several approaches, as methodological bases of achievement of the purpose of our research, we consider the technological approach in a in the perspective of application of a certain set of pedagogical technologies in educational process of establishments of higher (technologies of problem-based learning and group work, design, interactive and game technologies), which, in our opinion, are a priority in the formation of ecological competency of future teachers of natural sciences. The relevance of these technologies is due to the challenges facing higher pedagogical education in the training of teachers with professional competencys necessary for the implementation of training and education of the younger generation in a post-industrial society.

At the same time, the personal development of the future teacher aims at continuous improvement of the level of formation of his professional competencys, which according to A. A. Verbickij, can be carried out through the comprehension of the acquired knowledge, which occurs due to the restructuring of the past experience of the learner, taking into account the new content of information in relevant practical situations. That is, educational information must be assimilated in the context of its further practical use in activities, then it acquires value. These provisions were laid down by the researcher in the development of the theory of contextual learning, which later grew into a new methodological approach in education, which is closely related to the competency. "To become theoretically and practically competent, a student needs to make a double transition: from a sign (information) to a thought, and from a thought to an action. The transition from information to its use is mediated by thought, which makes this information meaningful knowledge", - says the scientist (Verbickij, 2004: 55).

Thus, the contextual approach in higher pedagogical education involves the saturation of the educational process with elements of professional pedagogical activity, then the acquired knowledge will be confirmed by actions and deeds in practice. An important feature of this approach, according to O.A. Dubaseniuk, O. B. Vozniuk is a consideration of pedagogical activity through the sphere of pedagogical values, which fill this activity (Dubaseniuk, Vozniuk, 2011: 94). Thus, the contextual approach makes it possible to fill the educational content of professional training of future teachers of natural sciences with the value and professional content through awareness and self-reflection of the acquired knowledge, skills and abilities.

From this we can conclude that it is necessary to apply a reflective approach in the training of future teachers, because it is the work of a teacher requires constant personal development, professional growth and self-improvement of their own pedagogical skills. Involvement of this approach in competence-oriented higher pedagogical education is justified by the need to develop a sense of responsibility of the individual for the actions, based on self-reflection and self-analysis of the results and consequences of their own activities, including professional.

The pedagogical dictionary states that reflection is not just knowledge or understanding of the subject himself, but finding out how others know and understand of the "reflector", his personal characteristics, emotional reactions, cognitive ideas (Yarmachenko, 2011: 398). Reflection as a personal quality of a teacher is substantiated in the work of V. D. Sharko, where it is interpreted as a professionally significant quality of the teacher, ie the ability of the teacher's mind to be focused not on the subject of their own activities, but on the activity itself. At the same time, as the author notes, reflection as a process is a comprehension of one's own activity, its analysis for the purpose of further purposeful improvement (Sharko, 2006: 141). Thus, summarizing these views, we can conclude that the reflexive approach in shaping the system of competencys of future teachers has a broad functional purpose: it performs the function of 
self-control of the effectiveness of their professional activities, development of responsibility for its consequences and stimulates professional self-development and self-improvement.

Relevant to the professional training of future teachers of natural sciences, especially in the context of the formation of their ecological competency, is the application of a relatively new in pedagogy coevolutionary-noosphere approach, identified by O. A. Dubaseniuk, O. B. Vozniuk. Scientists interpret it as " ...consideration into account in the process of human development various evolutionary environmental factors (including family, group, state, socio-cultural, socio-natural, cosmoplanetary), which must be combined, correspond to each other in order to create the effect of mutual potentiation (strengthening)" (Dubaseniuk, Vozniuk, 2011: 12). The genesis of ecological competency of an individual is influenced by factors that are determined by the dominant social ecological values and the state of the socio-natural environment on the one hand, and on the other - the educational development environment of educational institutions. Taking into account their impact on the formation of components of ecological competency of future teachers of natural sciences is carried out by building an educational process from the standpoint of concepts of coevolution of nature and society and sustainable development as a basis of implementation for humanistic values, noosphere thinking in the content of training of future teachers.

Naturally, the main role among these methodological approaches to the organization of the educational process of professional training of future teachers of natural sciences is assigned to the competency. In particular, the advantages of the competency approach in constructing the content of the educational process of vocational education were argued by S.V. Lisova. In her opinion, they are as follows (Lisova, 2011: 49):

- move in higher education from its focus on the reproduction of knowledge to the application and organization of knowledge;

- base a strategy to increase flexibility in favor of expanding employment opportunities;

- set as a basis interdisciplinary-integrated requirements for the outcome of the educational process;

- focus the activities of graduates on a variety of professional and life situations.

Competence approach in higher pedagogical education, according to the authors of the collective monograph "Professional pedagogical education: competence approach", combines elements of professional and general culture, experience and creativity, which together characterize the level of integration of future professionals in the professional environment (Dubaseniuk, Vozniuk, 2011: 11). Thus, the competence approach in the modernization of higher education should provide training and education of students from an activity standpoint, which will contribute to the experience of a holistic systemic vision of their future professional teaching, choosing the best ways to effectively solve new problems and tasks.

In this perspective, the opinion is relevant of O. L. Zhuk, which identified four main functions of the competence approach in education (Zhuk, 2008):

- operational, which involves the identification (operationalization) of the system of knowledge, skills and abilities, types of student readiness, which determine its competence and guarantee the effectiveness of professional, social and personal tasks;

- activity-technological, which provides construction of the content of activity-type learning, maximum approximation to the future sphere of the student's activity, development and introduction into the educational process of tasks, the methods of solving which correspond to the technologies of professional activity;

- educative, which means strengthening the educative component of the educational process, the formation of students organizational and managerial experience, the culture of personal and professional communication; 
- diagnostic, which involves the development of a more effective system for monitoring the quality of the educational and professional process, in particular, the diagnosis of the achieved levels of competencies.

In turn, the introduction of a competency-based approach to the practice of higher pedagogical education, in our opinion, makes it possible to achieve the following educational goals (Siaska, 2018: 175):

- structuring the system of knowledge in order not only to reproduce them, but also to apply, ie reorientation from declarative knowledge to procedural;

- formation of a number of general competencys, which significantly expands the opportunities for further employment of the graduate;

- strengthening the interdisciplinary content of education, necessary for effective activity in the information-post-industrial society;

- inclusion in the educational process of search and problem-research activities with strengthening of its practical orientation;

- intensification of independent work of students, their involvement in public activities with the acquisition of organizational, managerial and communicative experience.

\section{Methodological bases and pedagogical regularities of professional training of future teachers of natural sciences}

The most common regulators that are part of the methodological support of pedagogical research are methodological bases, which are based on the relevant philosophical provisions. We have identified the methodological basis for the implementation of the competency approach in the process of environmental education of students of natural faculties of higher pedagogical educational institutions in order to form the ecological competency of future teachers of natural sciences:

- ontological philosophical and cultural provisions on the dialectical knowledge of phenomena and processes of interdependence and interaction of nature and man, which substantiate the ideas of coevolution, sustainable development of nature and society and the need to harmonize interactions in the system "nature - human - society";

- epistemological concept, which characterizes the main stages of the learning process (feeling, perception, understanding, understanding, generalization, consolidation, application) and reflects the relationship of knowledge, values and motivational components as the basis of behavior and activities of the individual in the environment;

- axiological recognition of the subjective attitude to nature and the non-pragmatic nature of interaction with it, which is based on the priority of environmental value orientations;

- praxeological principles of effective ecologically expedient activity in the environment, taking an active ecological position in the process of solving professional and life situations on the basis of the formed system of ecological values in relation to nature.

The implementation of these methodological basis for the educational process of higher education is based on certain pedagogical regularities, which by definition S.G. Goncharenko, reflect the objective, stable and essential connections that determine the effectiveness of the educational process (Goncharenko, 1997: 131). In pedagogy there is no single approach to the separation and classification of regularities of the pedagogical process, because according to A. V. Hutorskoj, each didactic system is based on a special set of pedagogical regularities (Hutorskoj, 2007: 86). Therefore, scientists distinguish general pedagogical regularities that reflect the whole pedagogical process, and partial, when their action extends only to certain components of the educational process). 
In accordance with the purpose and objectives of our study, we have identified a list of general pedagogical regularities of competence-oriented education and partial regularities, determined by the peculiaritys of professional training of future teachers of natural sciences in the context formation of their ecological competency.

On the basis of the analysis of scientific works to the first group we carried the generally accepted regularitiesof pedagogical process concerning professional training of future teachers: 1) conditionality of pedagogical process to needs of a society and the person (post-industrial society needs competent specialists - teachers with established life and professional competencys, able to carry out adequate education and upbringing of student youth in accordance with modern requirements); 2) personal development (in the process of professional training due to the influence of the educational environment is the development of personal qualities as a basis for the formation of the system of competencys of the future specialist); 3 ) management of the pedagogical process (regulation and correction of the educational process taking into account the feedback between its subjects allows to ensure the effectiveness of the pedagogical impact on the professional training of teachers); 4) stimulation and motivation (the effectiveness of the educational process depends on external incentives - social, material, pedagogical and internal motivation of the students); 5) unity of sensory, logical and practice (based on the psychological features of the formation of emotional-sensory, abstract-logical and associative connections during the perception and assimilation of educational material and its effective application in practice in solving pedagogical problems or situations); 6) the unity of the task, content, forms, methods and means of the educational process with the expected results of training (determines the feasibility of choosing the components of the educational process in accordance with the objectives and achieving educational results - the formation of life and professional competencys of future teachers); 7) the dynamics of the pedagogical process (compliance with the sequence and stages of personal and professional growth of students in the process of professional training); 8) the integrated result of the pedagogical process (taking into account all the relationships that arise between objects, subjects and stages of the educational process is the key to its success and effectiveness).

In the context of this issue, the study of N. D. Andreeva is relevant, in which she substantiated the pedagogical regularities of formation of the content of environmental education of student-biologist in order to prepare them for environmental and pedagogical activities (Andreeva, 2000: 31-32). The general regularities identified by the author reflect the links between the components of the educational process and its subjects and their interaction with the process of ecological and pedagogical training of students, which ensures the integrity of the structure of the educational system in higher pedagogical education.

Taking into account the above developments and taking into account the above general regularities of competence-oriented education in the process of professional training of future teachers, we have identified partial pedagogical regularities that govern and ensure the effectiveness of ecological competency of future teachers of natural sciences:

1) socio-pedagogical conditionality of the content of environmental education and upbringing in higher education institutions in accordance with the public demand for sustainable development of nature and society;

2) functional dependence of the content on the purpose and tasks of competence ecological education and education of students, caused by educational standards;

3 ) the unity of the structural components of the educational process (content, forms, methods, tools), aimed at forming the ecological competency of future teachers of natural sciences; 
4) interdisciplinary interaction of humanitarian and natural science education in the formation of ecological value orientations, ecological consciousness, culture and worldview of student youth;

5) stages and sequence of the relationship of theoretical and practical ecological training of future teachers with the gradual acquisition of experience in their application in professional activities;

6) the relationship between the development of personal qualities of students (interests, needs, motives, beliefs, subjective attitude to nature) with the formation of ecological competency of future teachers.

\section{Conclusions}

In domestic pedagogy, a significant contribution has been made to the development of theoretical and methodological approaches to the organization of competence-oriented education. However, most studies relate to the formation of key competencys in general secondary education or have a general pedagogical orientation. Therefore, the introduction of a competency-based approach in the process of professional training of teachers of natural sciences is an urgent problem and requires a detailed theoretical and methodological justification. Defined methodological approaches and bases, general and partial pedagogical regularities of organization of educational process of professional training in the context of realization of ecological education of students, allow to build strategically correctly conceptual model of formation of ecological competency of future teachers of natural sciences. In particular, the organic combination of methodological approaches (competence, system, personality-oriented, activity, technological, contextual, reflective and coevolutionary-noosphere) on the principle of synergetic interaction is the methodological basis for determining the content, forms, means and technologies of environmental competence of future teachers. in the process of their professional training. The formation of ecological competency of the future teacher of natural sciences involves the need to ensure effective pedagogical conditions and appropriate organization of the educational environment in the institution of higher pedagogical education, the development of assessment tools to check the level of formation.

\section{References}

Andreeva, N. D. (2000). Sistema ekologo-pedagogicheskogo obrazovaniya studentov-biologov $v$ pedagogicheskom vuze [The system of ecological and pedagogical education of biology students in a pedagogical university]: Extended abstract of doctor's thesis. Sankt-Peterburg [in Russian].

Bekh, I. D. (1998). Osobystisno zoriientovane vykhovannia [Personally oriented education]. Kyiv: IZMN [in Ukrainian].

Bespalko, V. P. (1989). Slagaemye pedagogicheskoj tehnologii [Components of pedagogical technology]. Moskva: Pedagogika [in Russian].

Blauberg, I. V., Yudin, E. G. (1973). Stanovlenie i sushnost sistemnogo podhoda [Formation and essence of the system approach]. Moskva: Nauka [in Russian].

Burhun, I. V. (2010). Aktualnist uprovadzhennia kompetentnisnoho pidkhodu v ukrainskii osviti [The urgency of introducing a competency-based approach in Ukrainian education]. Aktualni problemy derzhavnoho upravlinnia, pedahohiky ta psykholohii. Zbirnyk naukovykh prats Khersonskoho natsionalnoho tekhnichnoho universytetu, issue 2, 159-165 [in Ukrainian]. 
Common European Principles for Teacher Competences and Qualifications. European Commission.

Dubaseniuk, O. A., Vozniuk, O. V. (2011). Kontseptualni pidkhody do profesiino-pedahohichnoi pidhotovky suchasnoho pedahoha [Conceptual approaches to professional and pedagogical training of a modern teacher]. Profesiina pedahohichna osvita: kompetentnisnyi pidkhid. O. A. Dubaseniuk. (Ed.). Zhytomyr, 11-18 [in Ukrainian].

Education and Training 2010 Programme. (2008). Joint seminar Report. Cluster "Key Competences - Curriculum Development".

Fokshek, A. V. (2011). Systemnyi ta synerhetychnyi pidkhody u modeliuvanni suchasnoho pedahohichnoho protsesu [System and synergetic approaches in modeling the modern pedagogical process]. Naukovyi visnyk Melitopolskoho derzhavnoho pedahohichnoho universytetu imeni Bohdana Khmelnytskoho. Seriia: Pedahohika, 6, 213-220 [in Ukrainian].

Honcharenko, S. U. (2008). Pedahohichni doslidzhennia: metodolohichni porady molodym naukovtsiam [Pedagogical research: methodological advice for young scientists]. Kyiv; Vinnytsia: DOV "Vinnytsia" [in Ukrainian].

Honcharenko, S. (1997). Ukrainskyi pedahohichnyi slovnyk [Ukrainian pedagogical dictionary]. Kyiv: Lybid [in Ukrainian].

Hutorskoj, A. V. (2007). Sovremennaya didaktika [Modern didactics]. Moskva: Vysshaya shkola. Kremen, V. (2013). Pedahohichna synerhetyka: poniatiino-katehorialnyi syntez [Pedagogical synergetics: conceptual and categorical synthesis]. Teoriia i praktyka upravlinnia sotsialnymy systemamy, 3, 3-19 [in Ukrainian].

Lisova, S. V. (2011). Kompetentnisnyi pidkhid u vyshchii osviti: zarubizhnyi dosvid [Competence approach in higher education: foreign experience]. Profesiina pedahohichna osvita: kompetentnisnyi pidkhid. O. A. Dubaseniuk. (Ed.). Zhytomyr, 34-53 [in Ukrainian].

Pedahohichnyi slovnyk [Pedagogical dictionary]. M.D. Yarmachenko (Ed.). (2001). Kyiv: Pedahohichna dumka [in Ukrainian].

Piekhota, O. M., Kiktenko, A. Z., Liubarska, O. M. et al. (2001). Osvitni tekhnolohii [Educational technologies]. Kyiv: A.S.K. [in Ukrainian].

Rybalko, L. (2014). Navchannia pryrodnychykh predmetiv na zasadakh ekoloho-evoliutsiinoho pidkhodu $v$ zahalnoosvitnikh navchalnykh zakladakh: teoriia i praktyka [Teaching natural subjects on the basis of ecological-evolutionary approach in secondary schools: theory and practice]. Poltava: FOP Myron I.A. [in Ukrainian].

Selevko, G. K. (2006). Enciklopediya obrazovatelnyh tehnologij [Encyclopedia of educational technologies]. (Vols. 1-2; Vol. 1). Moskva: NII shkolnyh tehnologij [in Russian].

Sharko, V. D. (2006). Teoretychni zasady metodychnoi pidhotovky vchytelia fizyky v umovakh neperervnoi osvity [Theoretical bases of methodical preparation of the teacher of physics in the conditions of continuous education]: Doctor's thesis. Kyiv [in Ukrainian].

Siaska, I. (2018). Do problemy vprovadzhennia kompetentnisnoho pidkhodu u protses fakhovoi pidhotovky maibutnikh uchyteliv pryrodnychykh dystsyplin [To the problem of introduction of the competence approach in the process of professional training of future teachers of natural sciences]. Pedahohichni nauky: teoriia, istoriia, innovatsiini tekhnolohii, 10 (84), 179-189 [in Ukrainian].

Verbickij, A. A. (2004). Kompetentnostnyj podhod i teoriya kontekstnogo obucheniya [Competence approach and contextual learning theory]. Moskva: IC PKPS [in Russian].

Zhuk, O. L. (2008). Belarus: kompetentnostnyj pohod v pedagogicheskoj podgotovke studentov universiteta [Belarus: Competence-Based Approach in Pedagogical Training of University Students]. Pedagogika, 3, 99-105 [in Belarusian]. 